\title{
Response of plasma glucose, insulin, and nonesterified fatty acids to intravenous glucose tolerance tests in dairy cows during a 670-day lactation
}

\author{
L. C. Marett, ${ }^{* 1}$ M. J. Auldist, ${ }^{*}$ P. J. Moate, ${ }^{*}$ W. J. Wales, ${ }^{*}$ K. L. Macmillan, † F. R. Dunshea, $\ddagger$ and B. J. Leurył \\ ${ }^{*}$ Agriculture Research Division, Department of Environment and Primary Industries, Ellinbank, Victoria 3821, Australia \\ †Faculty of Veterinary Science, The University of Melbourne, Werribee, Victoria 3030, Australia \\ $\ddagger$ Melbourne School of Land and Environment, The University of Melbourne, Parkville, Victoria 3010, Australia
}

\section{ABSTRACT}

This experiment investigated the metabolic response of dairy cows undergoing an extended lactation to a frequently sampled intravenous glucose tolerance test. The experiment used 12 multiparous Holstein cows that calved in late winter in a seasonally calving pasture-based system and were managed for a 670-d lactation by delaying rebreeding. In each of four 5 -wk experimental periods commencing at approximately 73 , 217,422 , and $520( \pm 9.1)$ days in milk (DIM), cows were offered a diet of perennial ryegrass (73 and 422 DIM) or pasture hay and silage (217 and 520 DIM) supplemented with $1 \mathrm{~kg}$ of DM grain (control; CON) or $6 \mathrm{~kg}$ of DM grain (GRN) as a ration. Daily energy intake was approximately 160 and 215 MJ of metabolizable energy/cow for the CON and GRN treatments, respectively. At all other times, cows were managed as a single herd and grazed pasture supplemented with grain to an estimated minimum daily total intake of $180 \mathrm{MJ}$ of metabolizable energy/cow. Cows were fitted with an indwelling jugular catheter during the final week of each experimental period. The standard intravenous glucose tolerance test using $0.3 \mathrm{~g}$ of glucose per kilogram of body weight was performed on each cow at approximately 100, 250, 460, and 560 DIM. Plasma concentrations of glucose, insulin, and nonesterified fatty acids (NEFA) responses were measured. Milk yield, milk solids yield, body weight, and basal plasma glucose were greater in the GRN compared with the CON treatment. The area under the plasma response curve relative to baseline (AUC) for glucose, insulin, and NEFA and their apparent fractional clearance rates indicated varied whole body responsiveness to insulin in terms of glucose metabolism throughout the $670-\mathrm{d}$ lactation. The glucose AUC 0 to 20 min postinfusion was increased at 560 DIM, indicating reduced utilization of glucose by the mammary gland at this stage

Received April 3, 2014.

Accepted September 22, 2014.

${ }^{1}$ Corresponding author: leah.marett@depi.vic.gov.au of lactation. The NEFA clearance rate, 6 to $30 \mathrm{~min}$ postinfusion, was greater at 460 and 560 DIM. These data indicated an increase in lipogenic activity or a decrease in lipolysis as lactation progressed, suggestive of an overall increase in responsiveness to insulin in terms of whole body lipid metabolism as lactation progressed. These observations are consistent with decreased priority of lactation beyond 300 DIM. Cows in the GRN treatment had decreased whole body responsiveness to hyperglycemia compared with CON cows in terms of glucose clearance and AUC for the glucose response. Variation in the response curves of plasma glucose, NEFA, and insulin was predominantly a result of stage of lactation and not diet. This may be due to changes in mammary gland uptake of glucose that is independent of insulin and the responsiveness of peripheral tissues to the actions of insulin at different stages of the lactation that are independent of diet.

Key words: extended lactation, glucose tolerance, insulin sensitivity, fatty acid metabolism

\section{INTRODUCTION}

Dairy farm systems that incorporate extended lactations up to $670 \mathrm{~d}$ alleviate the need for cows to conceive during peak production. Such systems can allow farmers to take advantage of the reduced risk of metabolic disorders, lowered costs associated with reproduction, and milk price incentives during winter (Borman et al., 2004), yet with minimal loss in annualized milk solids production (Auldist et al., 2007; Kolver et al., 2007). Previous experiments have shown marked variation in the milk production capacity of Holstein cows undergoing extended lactations in pasture-based dairying systems (Auldist et al., 2007; Grainger et al., 2009; Kay et al., 2009). It is known that genotype interacts with diet (Kolver et al., 2007; Sorensen et al., 2008; Grainger et al., 2009) in terms of extended lactation capacity in grazing systems. However, less is known about the physiological regulation of nutrient partitioning during extended lactations.

Some of the difference in extended lactation capacity is due to variation in nutrient partitioning (Delany et 
al., 2010; Marett et al., 2011). These studies showed that cows with greater lactation persistency (i.e., beyond $300 \mathrm{~d}$ ) had higher blood plasma concentrations of growth hormone and NEFA, but lower concentrations of insulin, glucose, and leptin beyond 300 DIM. Cows that were unable to complete a full 670-d lactation gained more BW and BCS than those that were able to continue milking. Dietary restriction under grazing conditions did not decrease the proportion of cows reaching the target 670-d lactation length (Delany et al., 2010; Marett et al., 2011). However, cows fed energy in excess of requirements were less likely to complete the 670-d lactation (Grainger et al., 2009; Delany et al., 2010). Low plasma concentrations of insulin have been reported throughout early lactation compared with the mid and late stages of a traditional lactation (Ronge et al., 1988; Busato et al., 2002; Reist et al., 2002). This occurs because the mammary gland generally does not require insulin to facilitate the movement of glucose across the cell membrane for milk production (Collier et al., 1984), thus low plasma insulin favors the partitioning of nutrients from peripheral tissue deposition. In addition, decreased responsiveness to insulin has been reported just before and after parturition in lactating goats (Debras et al., 1989), sheep (Prior and Christenson, 1978), and cows (Sano et al., 1993; Bell and Bauman, 1997; Vernon and Pond, 1997). These adaptations result in a positive relationship between milk yield and insulin resistance, as demonstrated by low responsiveness of insulin-dependent tissues to the actions of insulin in cows with high milk yield (Cronje, 2000; Chagas et al., 2009).

Some of the variation in nutrient partitioning beyond $300 \mathrm{~d}$ of lactation may be due to differences in insulin sensitivity. Patton et al., (2009) reported a greater clearance rate $(\mathbf{C R})$ of glucose during an intravenous glucose tolerance test (IVGTT) in Holstein-Friesian cows of predominantly New Zealand ancestry compared with North American ancestry in early and midlactation (32 and 127 DIM respectively) and suggested this may be associated with greater tissue accretion in the lower-yielding New Zealand cows. It has been shown that insulin sensitivity during the nonlactating period was not related to feed intake (Schoenberg et al., 2012), but in an experiment by Pires et al. (2007) the infusion of tallow, which resulted in elevated plasma triglyceride concentrations, was associated with decreased sensitivity to insulin. Bergman et al. (1989) showed that lean sheep had greater insulin sensitivity than obese sheep, in addition to lower plasma concentrations of glucose and insulin, highlighting the link between FA metabolism and glucose sensitivity. As milk yield declines and the proportion of nutrients partitioned to body tissue gain increases, insulin sensitivity may be enhanced.
Currently no reports exist on insulin sensitivity in relation to glucose or FA metabolism of cows undergoing lactations longer than $300 \mathrm{~d}$.

A better understanding of the metabolic and hormonal regulation of nutrient partitioning is important in developing nutritional strategies for cows managed for extended lactations. In the experiments described here, the frequently sampled IVGTT was employed at several stages of a 670-d lactation to investigate whole body glucose metabolism and insulin sensitivity. The goal of these experiments was to identify sources of variation in metabolic responses to hyperglycemia and a consequent increase in endogenous insulin in cows undergoing an extended lactation. A further goal was to determine whether this variation was affected by cereal grain intake. The hypotheses tested were (1) that the estimated whole body sensitivity, in terms of the insulin, glucose, and FA responses to a glucose load, would increase with increasing DIM, and (2) that the dietary intake of cereal grain would not affect the estimated whole body insulin sensitivity, in terms of insulin, glucose, and FA responses to a glucose load.

\section{MATERIALS AND METHODS}

\section{Location}

This experiment was conducted at the Department of Environment and Primary Industries' Ellinbank Centre in Victoria, Australia $\left(38^{\circ} 14^{\prime} \mathrm{S}, 145^{\circ} 56^{\prime} \mathrm{E}\right)$. All procedures were approved by the Department of Primary Industries Eastern Animal Ethics Committee.

\section{Cows and Management}

The experiment used 12 multiparous Holstein-Friesian dairy cows of mixed age that calved in late July (midlate winter). These cows were a subset of those used in the experiments of Auldist et al. (2011). All cows were managed for an extended lactation by delaying breeding until approximately 450 DIM. This equated to a target lactation length of $670 \mathrm{~d}$. For the majority of the lactation (excluding experimental periods), cows were managed as a single herd and grazed perennial ryegrass (Lolium perenne L.) pasture supplemented with cereal grain fed twice daily in the parlor at milking times. When pasture was limiting during the summer and autumn months, pasture hay (approximately $6 \mathrm{~kg}$ of $\mathrm{DM} /$ cow per day) and pasture silage (approximately 10 $\mathrm{kg}$ of $\mathrm{DM} /$ cow per day) were also offered to achieve an estimated daily intake of $180 \mathrm{MJ}$ of ME/cow.

During the lactation, 4 experimental periods of $40 \mathrm{~d}$ were used, beginning at each of $73,217,422$, and 520 $( \pm 9.1)$ DIM. During these periods, cows were housed 
either in individual stalls, where daily feed intake and milk yield were recorded, or in stand-off paddocks. After $35 \mathrm{~d}$, cows were relocated to metabolism stalls, where the IVGTT were conducted when cows were an average of approximately 100, 250, 460, and 560 DIM. Cows had previously been acclimated to metabolism stalls.

Two treatments were used, and each allocated randomly to 6 cows. Treatment groups were balanced for parity, calving date, BW, and yields of milk, protein, and fat in the preceding lactation (Baird, 1994). Cows returned to the same groups and were assigned the same treatments for subsequent experimental periods. During the experimental periods, the first group of cows was fed $1 \mathrm{~kg}$ of DM grain/d (control; CON) and the second group of cows was fed $6 \mathrm{~kg}$ of DM grain/d (GRN), with $50 \%$ of the total daily grain intake fed individually in the parlor at each milking.

During the first and third experimental periods (starting when cows were an average of 73 and 422 DIM), all cows were offered freshly cut ryegrass pasture (Lolium perenne L.); during the second and fourth experimental periods (starting when cows were an average of 217 and 520 DIM), when pasture was not readily available, alfalfa hay (Medicago sativa) and pasture silage was fed instead. The targeted daily intake of ME provided by the base diet of pasture or silage and hay was approximately $150 \mathrm{MJ}$ of ME/cow. Taking into account the energy from grain, the targeted total ME intake was approximately $160 \mathrm{MJ}$ of $\mathrm{ME} /$ cow per day for the CON treatment and $215 \mathrm{MJ}$ of ME/cow per day for the GRN treatment. During the first experimental period the grain used was triticale $(\times$ Triticosecale, a hybrid of wheat and rye Secale) that has similar nutritional characteristics to wheat. During the second, third, and fourth experimental periods, the grain used was wheat (Triticum).

All cows were housed indoors for the duration of the 5 -wk experimental periods. Forage and freshly cut pasture were fed twice daily in individual feed bins and cows were restrained in stalls. Grain was fed twice daily in individual feed bins at milking times. Cows were released from stalls to a loafing pad after they had eaten and had ad libitum access to fresh water. Cows were milked twice daily at approximately 0700 and $1500 \mathrm{~h}$.

The dry-off threshold and breeding program was implemented as described previously by Auldist et al. (2007). Some cows were removed from the experiment because their milk yield fell below the dry-off threshold (30 kg/cow per week for $2 \mathrm{wk}$ ) or because of unrelated health issues. During the experiment, $4 \mathrm{CON}$ and 2 GRN cows were replaced with cows of comparable age, DIM, milk yield, and the same dietary treatment.

\section{Measurements and Analyses}

Milk yield was measured for each cow at every milking during the experiment using a DeLaval Alpro milk metering system (DeLaval International, Tumba, Sweden). A composite sample of the daily milk (morning and evening) was collected using in-line milk meters (DeLaval International) every $2 \mathrm{wk}$ during the nonexperimental periods and weekly during the experimental periods. These samples were tested for concentrations of fat, protein, and lactose using an infrared milk analyzer (model 2000, Bentley Instruments, Chaska, MN).

Each cow was weighed every 2 wk during the nonexperimental periods but weekly during the experimental periods. Feed offered and refused was weighed daily during the experimental periods. Samples of pasture offered and refused were taken at every feeding, and of grain offered once per week, for the determination of DM concentration. Each sample was frozen, freezedried, ground through a $0.5-\mathrm{mm}$ sieve, and analyzed for nutritive characteristics by near-infrared spectroscopy by a commercial laboratory (Dairy One Forage Laboratory, Ithaca, NY). Nutritive characteristics of the diets are reported by Auldist et al. (2011) and Williams et al. (2013).

\section{IVGTT}

Each cow was fitted with an indwelling jugular catheter under local anesthesia during the final week of the experimental periods. They had food removed for 12 $\mathrm{h}$ before the IVGTT. Blood samples were collected at 20, 10, and $1 \mathrm{~min}$ before intravenous injection of $0.3 \mathrm{~g}$ of glucose $/ \mathrm{kg}$ of BW ( $50 \%$ dextrose solution). Blood samples were then collected at $2,3,4,5,6,8,10,12$, $15,18,20,22,25,30,35,40,45,50,55,60,75,90$, $120,150,180,210$, and $240 \mathrm{~min}$ after glucose infusion. Each sample was collected into heparinized Vacutainers (BD Vacutainer Systems, Plymouth, UK), immediately chilled on ice, and then centrifuged at $1,800 \times g$ for 10 min at $4^{\circ} \mathrm{C}$ within $1 \mathrm{~h}$ of collection. Plasma was decanted and stored at $-20^{\circ} \mathrm{C}$ until analyzed for glucose, insulin, and NEFA concentrations.

Plasma glucose concentration $(\mathrm{m} M)$ was measured using a commercially available kit (Thermo Infinity Glucose Oxidase Liquid, Thermo Fisher, Noble Park, Victoria, Australia). Plasma NEFA was measured using the commercially available Wako NEFA-C kit (Wako Chemicals USA, Richmond, VA) adapted for 96-well microplates (Johnson and Peters, 1993). Insulin in plasma was measured in duplicate by double-antibody RIA method described by Tindal et al. (1978). Insulin antiserum was raised in a guinea pig using bovine insulin (BI 4499, Ely Lilly Pty Ltd., West Ryde, NSW, 
Australia). Cross-reactions were $100 \%$ with bovine insulin (lot 016666; NOVO Bio Labs, Cambridge, MA). All samples were analyzed in duplicate. Intra- and interassay coefficients of variation were $<3$ and $<0.5 \%$ for glucose; $<4$ and $<6 \%$ for NEFA; and $<5$ and $9 \%$ for insulin, respectively.

\section{Calculations, Modeling, and Statistical Analyses}

The trapezoidal method was used to calculate the area under the response curve above baseline for each of plasma glucose, insulin, and NEFA. Clearance rates were expressed as the apparent fractional rate of change for a given time period and were determined from the slope of the natural logarithm of the plasma concentration (glucose, insulin, or NEFA) plotted against time.

The model used to fit the plasma glucose response to the plasma insulin data was the glucose minimal model of Bergman et al. (1979), and the computer software used to fit this model was MINMOD Millennium (Boston et al., 2003; MINMOD Inc., Pasadena, CA). This model is used to calculate insulin sensitivity, or the ability of insulin to accelerate glucose disposal, within the body following a glucose challenge. It differs from the previous minimal model (Bergman et al., 1987; MINMOD Inc.) that described pancreatic sensitivity to glucose injection, or the effect of glucose to stimulate insulin secretion by the pancreas. The parameters and indices provided by the MINMOD software include: $\mathrm{Gb}=$ basal glucose concentration prechallenge (mg/ $\mathrm{dL}) ; \mathrm{Ib}=$ basal insulin concentration pre challenge $(\mathrm{mU} / \mathrm{L}) ; \mathrm{S}_{\mathrm{I}}=$ insulin sensitivity $(\mathrm{mU} / \mathrm{L}$ per minute), quantifies the capacity of insulin to promote glucose disposal through the GLUT4 receptors and to inhibit the endogenous production of glucose; $\mathrm{S}_{\mathrm{G}}=$ glucose effectiveness (per minute), capacity of glucose to mediate its own disposal through GLUT1 receptors; $\mathrm{AIR}_{\mathrm{g}}=$ acute insulin response to glucose (mU/L per minute), addresses adequacy of insulin secretion through $\beta$-cell function [defined as the area under the plasma insulin curve (AUC) between 0-10 min] and, as such, is a measure of pancreatic responsivity; and DI = disposition index (equals $\mathrm{AIR}_{\mathrm{g}} \times \mathrm{S}_{\mathrm{I}}$ ), combines information on the individual contributions of insulin sensitivity and pancreatic response to give the speed in which the subject responds to the glucose challenge.

Data were analyzed for differences in response measures at all 4 stages of the lactation $(100,250,460$, and 560 DIM) and between dietary treatments using a mixed model with REML (GenStat11.0; VSN International Ltd., Hemel Hempstead, UK). The model included fixed effects for DIM and diet with the cow as the random effect. For each plasma parameter, basal values were calculated by taking the average of the 3 samples before glucose infusion of each IVGTT. Recovery values were calculated as the average of the final 3 samples. Any skewed data for AUC or CR, plus that of $\mathrm{S}_{\mathrm{I}}$ and $\mathrm{AIR}_{\mathrm{g}}$, were analyzed after $\log 10$ transformation to stabilize the variance. Conclusions made from this analysis were similar to those from the analysis of the nontransformed data. The untransformed data are presented in the tables. Some data sets from individual cows were removed from the analyses due to poor fit of the minimal model to the data. This resulted in the data from 5 cows per treatment group being statistically analyzed for 100, 250, and 460 DIM, and 4 cows per treatment group for 560 DIM for minimal model analysis only.

\section{RESULTS}

\section{Milk Yield and Feed Intake}

Yields of milk, milk solids (fat + protein), and ECM were greatest at 100 DIM, intermediate at 250 and 460 DIM, and lowest at 560 DIM (Table 1). Yields of milk, milk solids, and ECM were greater in cows on the GRN treatment compared with the CON treatment, except at 250 DIM, where no difference in milk yield was observed. This was highly variable within diet at all stages of the lactation (range of milk yields: CON treatment $=21.8$ to $25.7,12.3$ to $25.7,6.7$ to $18.2,7.0$ to $12.5 \mathrm{~kg} / \mathrm{cow}$ per day and GRN treatment $=24.4$ to $33.3,16.5$ to $20.7,13.9$ to $21.2,9.2$ to $14.8 \mathrm{~kg} / \mathrm{cow}$ per day at 100, 250, 460 and 560 DIM, respectively). Milk composition was not affected by diet, although milk fat and protein concentrations increased with DIM in both treatments. Total DMI and ME intake were greater at 100 DIM compared with all other stages of the lactation and were consistently greater in the GRN treatment compared with the CON treatment. Interactions were noted between diet and DIM for milk yield and ME intake. Milk yield decreased significantly from 250 to 460 DIM in the CON treatment, whereas milk yield was maintained in the GRN treatment. Cow BW increased with increasing DIM, and GRN cows tended to be heavier at 460 and 560 DIM than CON cows.

\section{IVGTT}

Concentrations of glucose, NEFA, and insulin were measured in all plasma samples taken during all 4 IVGTT (Table 2, Figure 1). Basal plasma glucose concentration increased with increasing DIM and was greater in the GRN treatment than the CON treatment. Basal NEFA concentration was greatest at 250 DIM, intermediate at 100 and 460 DIM, and lowest at 560 DIM. Basal plasma insulin concentration was 


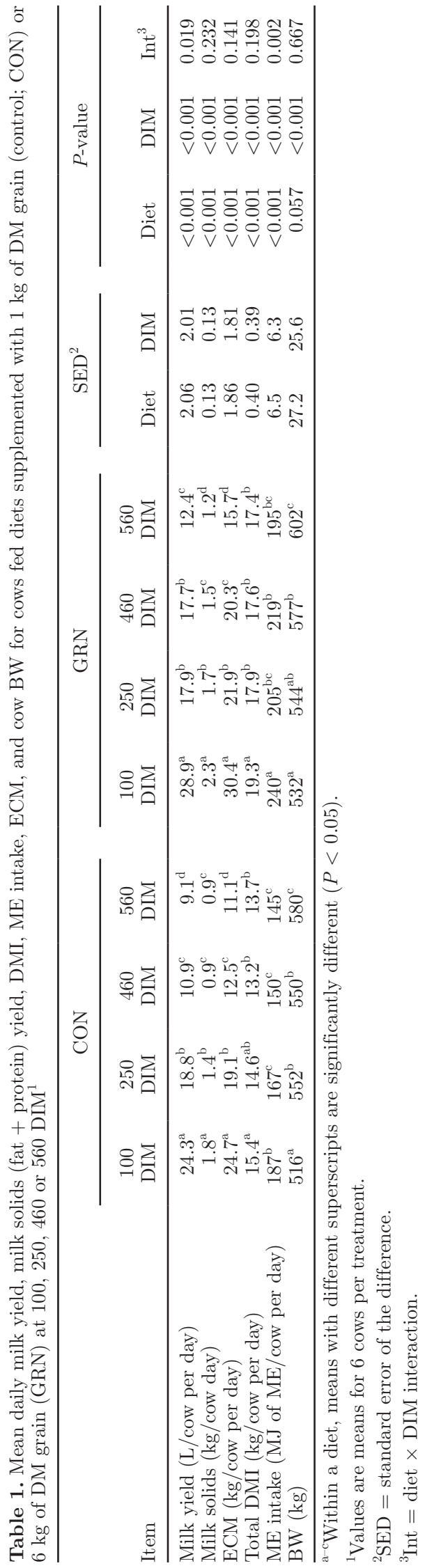

lower at 100 and 250 DIM compared with 460 and 560 DIM. Basal concentrations of NEFA and insulin were not affected by diet.

Plasma glucose concentration peaked immediately following infusion, reaching maximum concentrations 12 to 16 min post-glucose infusion (Table 2). Maximum glucose concentration measured after injection was greatest at 560 DIM compared with 100, 250, and 460 DIM, and was greater in GRN than CON cows. Recovery glucose concentrations generally reflected basal glucose concentrations, and were greater in GRN cows than CON cows. The initial fractional CR of glucose from plasma (CR 6-30 min) was not affected by stage of lactation or diet. The glucose CR 40 to $90 \mathrm{~min}$ was greatest at 100 DIM and was not affected by diet. The glucose AUC was greatest for the interval of 0 to 20 min postinfusion at 560 DIM compared with all other stages of lactation. No further effects of stage of lactation on glucose AUC and no effect of diet on glucose AUC were observed. Several interactions between diet and DIM occurred for the glucose response curve, including maximal glucose, glucose CR 40 to $90 \mathrm{~min}$, and $\mathrm{AUC}_{0-20}$ and $\mathrm{AUC}_{0-240}$, where subscript numbers indicate minutes postinfusion.

The peak insulin concentration (maximum insulin) in response to the glucose infusion was highly variable (range $=17$ to 170,10 to 110,18 to 82,19 to $72 \mathrm{IU} / \mathrm{mL}$ at 100, 250, 460, and 560 DIM, respectively) and was not significantly affected by DIM or diet (Table 2). The insulin CR 16 to 40 min was not affected by either diet or DIM. The rate of insulin clearance (CR 45-120 min) was greatest at 100 DIM and smallest at 250 DIM. The insulin $\mathrm{AUC}_{0-20}$ was not affected by diet but the insulin $\mathrm{AUC}_{0-240}$ was significantly greater in the GRN treatment compared with the CON. No interactions between diet and DIM were noted for the insulin response curve.

Plasma NEFA concentration decreased immediately following the glucose infusion at 100 DIM (Table 2). At all other stages of lactation plasma NEFA increased initially, followed by a decrease to a nadir (which was sometimes prolonged) between 30 and 90 min postglucose infusion. The minimum and recovery plasma NEFA concentration following glucose infusion reflected basal plasma NEFA concentration, being highest at 250 DIM, intermediate at 100 and 460 DIM, and lowest at 560 DIM. The percentage change in NEFA was positively related to DIM. The NEFA CR 6 to 30 min postinfusion was lower at 460 and 560 DIM than at 100 and 250 DIM. The NEFA $\mathrm{AUC}_{0-20}$ at 250, 460, and 560 DIM were positive, indicating the appearance of NEFA in the bloodstream rather than clearance, as observed at 100 DIM. Neither the CR nor AUC for the NEFA response was affected by diet. The AUC for the entire challenge were not affected by diet or DIM. 
Table 2. Plasma glucose, insulin and NEFA responses to infusion of glucose including basal and maximum, fractional rate change in blood (CR: minutes post-glucose infusion), and area under the response curve (AUC; minutes post-glucose infusion) for cows diets supplemented with $1 \mathrm{~kg}$ of DM grain (control; CON) or $6 \mathrm{~kg}$ of DM grain (GRN) at 100 , 250,460 , or $560 \mathrm{DIM}^{1}$

\begin{tabular}{|c|c|c|c|c|c|c|c|c|c|c|c|c|c|}
\hline \multirow[b]{2}{*}{ Item } & \multicolumn{4}{|c|}{$\mathrm{CON}$} & \multicolumn{4}{|c|}{ GRN } & \multicolumn{2}{|c|}{$\mathrm{SED}^{2}$} & \multicolumn{3}{|c|}{$P$-value } \\
\hline & $\begin{array}{c}100 \\
\text { DIM }\end{array}$ & $\begin{array}{c}250 \\
\text { DIM }\end{array}$ & $\begin{array}{c}460 \\
\text { DIM }\end{array}$ & $\begin{array}{c}560 \\
\text { DIM }\end{array}$ & $\begin{array}{c}100 \\
\text { DIM }\end{array}$ & $\begin{array}{c}250 \\
\text { DIM }\end{array}$ & $\begin{array}{c}460 \\
\text { DIM }\end{array}$ & $\begin{array}{c}560 \\
\text { DIM }\end{array}$ & Diet & DIM & Diet & DIM & Int $^{3}$ \\
\hline \multicolumn{14}{|l|}{ Glucose } \\
\hline Basal $(\mathrm{m} M)$ & $3.4^{\mathrm{a}}$ & $3.3^{\mathrm{a}}$ & $3.7^{\mathrm{ab}}$ & $3.9^{\mathrm{b}}$ & $3.8^{\mathrm{a}}$ & $3.8^{\mathrm{a}}$ & $3.7^{\mathrm{ab}}$ & $4.2^{\mathrm{b}}$ & 0.25 & 0.24 & 0.009 & 0.040 & 0.632 \\
\hline Maximum $(\mathrm{m} M)$ & $12.8^{\mathrm{a}}$ & $14.1^{\mathrm{a}}$ & $14.1^{\mathrm{a}}$ & $15.7^{\mathrm{b}}$ & $16.0^{\mathrm{ab}}$ & $13.7^{\mathrm{a}}$ & $13.3^{\mathrm{a}}$ & $18.1^{\mathrm{b}}$ & 1.24 & 1.20 & 0.058 & 0.001 & 0.050 \\
\hline Recovery $(\mathrm{m} M)$ & $3.4^{\mathrm{ab}}$ & $3.2^{\mathrm{a}}$ & $3.7^{\mathrm{bc}}$ & $3.9^{\mathrm{c}}$ & $3.6^{\mathrm{ab}}$ & $3.4^{\mathrm{a}}$ & $3.9^{\mathrm{bc}}$ & $4.3^{\mathrm{c}}$ & 0.25 & 0.24 & 0.019 & $<0.001$ & 0.869 \\
\hline CR $6-30(\% / \mathrm{min})$ & -1.7 & -1.9 & -1.9 & -2.0 & -2.1 & -1.9 & -1.7 & -2.1 & 0.34 & 0.33 & 0.554 & 0.829 & 0.627 \\
\hline CR $40-90$ (\%/min $)$ & $-1.11^{\mathrm{a}}$ & $-0.67^{\mathrm{b}}$ & $-1.00^{\mathrm{b}}$ & $-0.90^{\mathrm{b}}$ & $-1.45^{\mathrm{a}}$ & $-1.01^{\mathrm{b}}$ & $-0.67^{\mathrm{b}}$ & $-0.73^{\mathrm{b}}$ & 0.160 & 0.150 & 0.392 & $<0.001$ & 0.004 \\
\hline $\mathrm{AUC}_{0-20}(\mathrm{~m} M \cdot \min )$ & $140^{\mathrm{ab}}$ & $158^{\mathrm{a}}$ & $154^{\mathrm{a}}$ & $173^{\mathrm{b}}$ & $168^{\mathrm{ab}}$ & $128^{\mathrm{a}}$ & $135^{\mathrm{a}}$ & $174^{\mathrm{b}}$ & 13.8 & 13.3 & 0.530 & 0.008 & 0.016 \\
\hline $\mathrm{AUC}_{0-240}(\mathrm{~m} M \cdot \mathrm{min})$ & 298 & 446 & 360 & 370 & 333 & 117 & 331 & 403 & 109.9 & 106.0 & 0.138 & 0.509 & 0.048 \\
\hline \multicolumn{14}{|l|}{ Insulin } \\
\hline Basal $(\mu \mathrm{U} / \mathrm{mL})$ & $2.9^{\mathrm{ab}}$ & $2.3^{\mathrm{a}}$ & $3.3^{\mathrm{ab}}$ & $3.4^{\mathrm{b}}$ & $2.7^{\mathrm{ab}}$ & $2.6^{\mathrm{a}}$ & $4.1^{\mathrm{b}}$ & $3.1^{\mathrm{ab}}$ & 0.74 & 0.71 & 0.628 & 0.052 & 0.616 \\
\hline Maximum $(\mu \mathrm{U} / \mathrm{mL})$ & 35.9 & 20.9 & 41.2 & 39.3 & 63.2 & 36.6 & 48.7 & 41.5 & 17.15 & 16.54 & 0.116 & 0.328 & 0.724 \\
\hline Recovery $(\mu \mathrm{U} / \mathrm{mL})$ & $2.2^{\mathrm{ab}}$ & $1.7^{\mathrm{b}}$ & $3.0^{\mathrm{a}}$ & $2.2^{\mathrm{ab}}$ & $2.1^{\mathrm{ab}}$ & $2.4^{\mathrm{b}}$ & $2.9^{\mathrm{a}}$ & $2.3^{\mathrm{ab}}$ & 0.56 & 0.54 & 0.468 & 0.076 & 0.737 \\
\hline CR $4-12(\% / \mathrm{min})$ & 4.9 & 2.1 & 2.1 & 7.2 & 4.2 & 5.2 & 4.2 & 4.5 & 2.26 & 2.18 & 0.707 & 0.286 & 0.233 \\
\hline CR $16-40(\% / \mathrm{min})$ & -1.7 & -3.2 & -2.7 & -1.0 & -2.2 & -2.4 & -2.0 & -2.2 & 0.88 & 0.85 & 0.865 & 0.179 & 0.280 \\
\hline CR $45-120(\% / \mathrm{min})$ & $-2.7^{\mathrm{b}}$ & $-2.2^{\mathrm{a}}$ & $-2.3^{\mathrm{ab}}$ & $-2.9^{\mathrm{b}}$ & $-2.7^{\mathrm{b}}$ & $-1.6^{\mathrm{a}}$ & $-2.7^{\mathrm{b}}$ & $-2.5^{\mathrm{ab}}$ & 0.37 & 0.36 & 0.364 & 0.004 & 0.232 \\
\hline $\mathrm{AUC}_{0-20}(\mathrm{mU} \cdot \min )$ & 434 & 281 & 540 & 413 & 740 & 381 & 574 & 490 & 174.3 & 168.1 & 0.128 & 0.142 & 0.668 \\
\hline $\mathrm{AUC}_{0-240}(\mathrm{mU} \cdot \mathrm{min})$ & 1,213 & 729 & 1,118 & 1,127 & 2,071 & 1,492 & 1,546 & 1,409 & 454.7 & 438.5 & 0.011 & 0.394 & 0.756 \\
\hline \multicolumn{14}{|l|}{ NEFA } \\
\hline Basal $(\mu M)$ & $228^{\mathrm{bc}}$ & $300^{\mathrm{c}}$ & $169^{\mathrm{ab}}$ & $110^{\mathrm{a}}$ & $264^{\mathrm{bc}}$ & $337^{\mathrm{c}}$ & $208^{\mathrm{ab}}$ & $159^{\mathrm{a}}$ & 58.1 & 56.1 & 0.164 & 0.001 & 0.999 \\
\hline Minimum $(\mu M)$ & $65^{\mathrm{b}}$ & $113^{\mathrm{a}}$ & $79^{\mathrm{b}}$ & $68^{\mathrm{b}}$ & $77^{\mathrm{b}}$ & $131^{\mathrm{a}}$ & $86^{\mathrm{b}}$ & $86^{\mathrm{b}}$ & 19.6 & 18.9 & 0.169 & 0.001 & 0.963 \\
\hline Change in NEFA (\%) & $34^{\mathrm{ab}}$ & $38^{\mathrm{a}}$ & $51^{\mathrm{bc}}$ & $64^{\mathrm{c}}$ & $28^{\mathrm{a}}$ & $40^{\mathrm{ab}}$ & $49^{\mathrm{ab}}$ & $58^{\mathrm{c}}$ & 8.5 & 8.2 & 0.478 & 0.001 & 0.885 \\
\hline Recovery $(\mu M$ & $190^{\mathrm{bc}}$ & $286^{c}$ & $203^{\mathrm{ab}}$ & $118^{\mathrm{a}}$ & $354^{\mathrm{b}}$ & $348^{\mathrm{b}}$ & $202^{\mathrm{a}}$ & $202^{\mathrm{a}}$ & 53.3 & 51.4 & 0.005 & $<0.001$ & 0.149 \\
\hline CR 6-30 (\%/min) & $-3.3^{\mathrm{ab}}$ & $-4.1^{\mathrm{b}}$ & $-2.9^{\mathrm{ab}}$ & $-2.0^{\mathrm{a}}$ & $-4.4^{\mathrm{b}}$ & $-3.9^{\mathrm{b}}$ & $-3.4^{\mathrm{ab}}$ & $-2.17^{\mathrm{a}}$ & 0.77 & 0.74 & 0.324 & 0.002 & 0.653 \\
\hline CR $40-90(\% / \mathrm{min})$ & $-0.01^{\mathrm{a}}$ & $-0.09^{\mathrm{a}}$ & $-0.07^{\mathrm{a}}$ & $0.02^{\mathrm{a}}$ & $0.30^{\mathrm{a}}$ & $0.24^{\mathrm{a}}$ & $0.1^{\mathrm{a}}$ & $-0.01^{\mathrm{a}}$ & 0.471 & 0.458 & 0.370 & 0.961 & 0.940 \\
\hline $\mathrm{AUC}_{0-20}(\mathrm{~m} M \cdot \min )$ & $-786^{\mathrm{b}}$ & $42^{\mathrm{ab}}$ & $2074^{\mathrm{a}}$ & $720^{\mathrm{ab}}$ & $-783^{\mathrm{b}}$ & $296^{\mathrm{ab}}$ & $939^{\mathrm{a}}$ & $573^{\mathrm{a}}$ & 1037 & 1000 & 0.499 & 0.018 & 0.765 \\
\hline $\mathrm{AUC}_{0-240}(\mathrm{~m} M \cdot \mathrm{min})$ & $-22,240$ & $-24,421$ & 2,371 & $-1,655$ & $-14,681$ & $-14,452$ & $-4,691$ & $-1,853$ & 14849 & 14319 & 0.746 & 0.116 & 0.821 \\
\hline
\end{tabular}

${ }^{\mathrm{a}-\mathrm{c}}$ Within a diet, means with different superscripts are significantly different $(P<0.05)$.

${ }^{1}$ Values are means for 6 cows per treatment.

${ }^{2} \mathrm{SED}=$ standard error of the difference.

${ }^{3} \mathrm{Int}=$ diet $\times$ DIM interaction. 

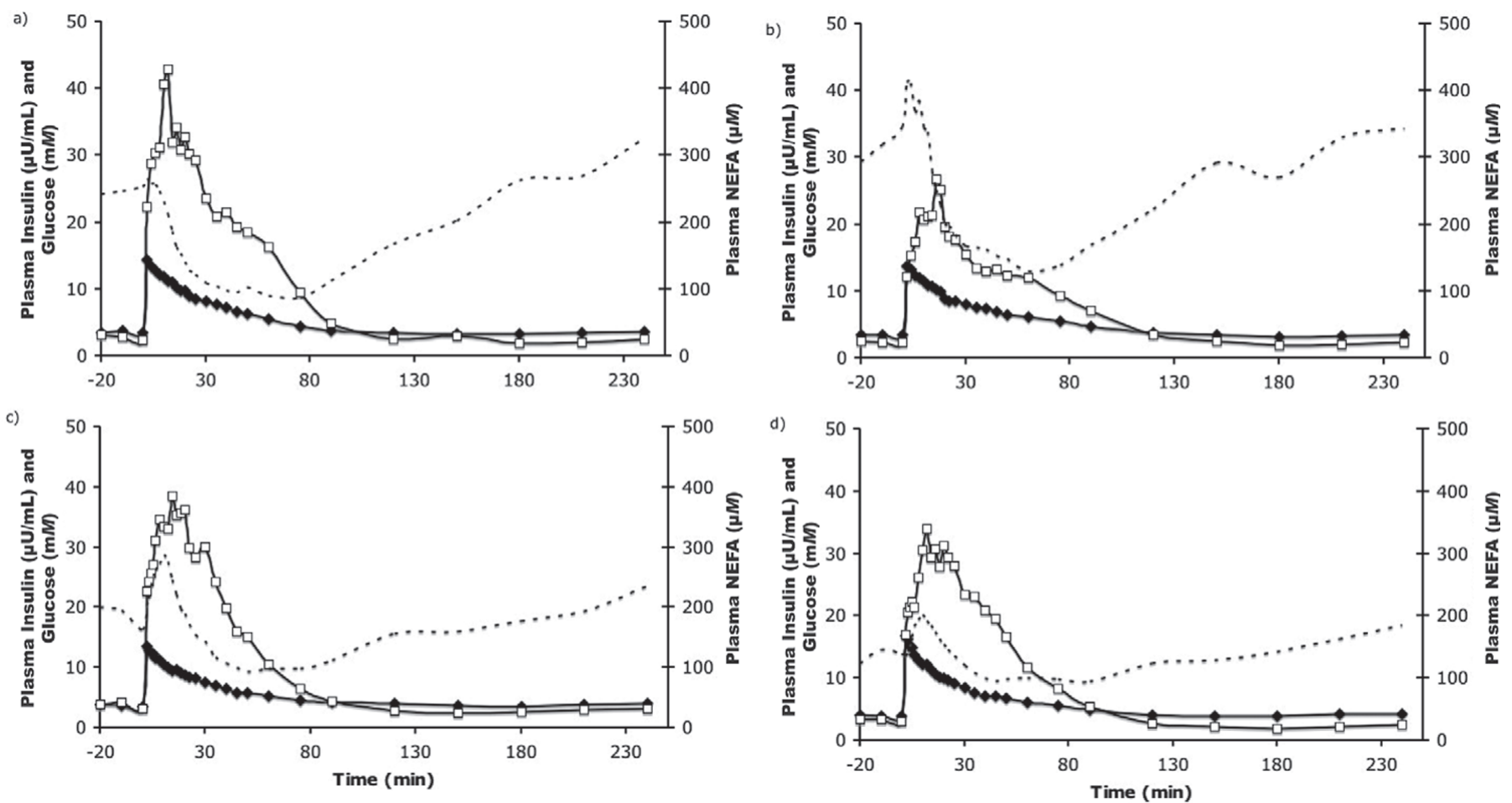

Figure 1. Plasma glucose $(\checkmark)$, insulin $(\square)$, and NEFA (- - ) response to glucose infusion $(0.3 \mathrm{~g} / \mathrm{kg}$ of BW) at time 0. Data are for challenges performed when cattle were at approximately (a) 100, (b) 250, (c) 460, and (d) 560 DIM. Data are combined for both treatments. Pooled SE for each stage of lactation were: glucose $=0.47,0.55,0.55$, and 0.73 ; insulin $=10.1,14.8,5.7$, and 5.3; and NEFA $=51.6,42.4,36.3$, and 19.6 , respectively.

No interactions between diet and DIM for the NEFA response curve were observed.

The MINMOD software was able to fit the majority of the IVGTT response curves (Figure 2), with equal numbers of CON and GRN response curves being fitted at each stage of lactation. Both DIM and diet affected basal plasma glucose concentration with no interaction (Table 3). Basal plasma glucose concentrations were greater at 460 and 560 DIM compared with 100 and 250 DIM, and greater in the GRN treatment compared with the CON, except at 460 DIM. At 100 DIM, the $\mathrm{AIR}_{\mathrm{g}}$ tended to be higher in the CON treatment than the GRN treatment $(P=0.100)$. No effects of DIM or diet were noted on any indices derived from the MINMOD software.

\section{DISCUSSION}

Reports of insulin sensitivity in lactating dairy cows are generally limited to the nonlactating state (Sartin et al., 1985; Holtenius et al., 2003; Pires et al., 2007), the transition period, and traditional lactations of up to $305 \mathrm{~d}$ in length (Denbow et al., 1986; Chagas et al., 2003; Holtenius et al., 2003). No data describing the responses of dairy cows to exogenous glucose in an extended lactation were found. Changes in response to insulin have been associated with onset of lactation (Sartin et al., 1985), age (McClary et al., 1988), and obesity (Bergman et al., 1989). This is the first report of IVGTT being used as an indirect method to evaluate the metabolic response of dairy cows to a glucose load at several stages of an extended lactation.

Milk yield decreased with increasing DIM (Table 1) and $\mathrm{BW}$ increased throughout lactation in both $\mathrm{CON}$ and GRN (Grainger et al., 2009; Marett et al., 2011). Higher basal plasma concentrations of glucose and insulin in the GRN cows reflected the higher DM and ME intake, and presumably a greater availability of propionate as a substrate for gluconeogenesis (Evans et al., 1975; Jenny and Polan, 1975). Consequently, basal plasma glucose and insulin concentrations were higher at 460 and 560 DIM compared with 100 and 250 DIM, consistent with reports regarding conventional (Ronge et al., 1988; Busato et al., 2002; Reist et al., 2002) and extended lactations (Sorensen and Knight, 2002; Delany et al., 2010; Marett et al., 2011), and this may contribute to the decrease in the partitioning of nutrients toward the mammary gland for milk synthesis during lactation.

Although the responses of individual cows to the IVGTT were highly variable, overall the response curves 


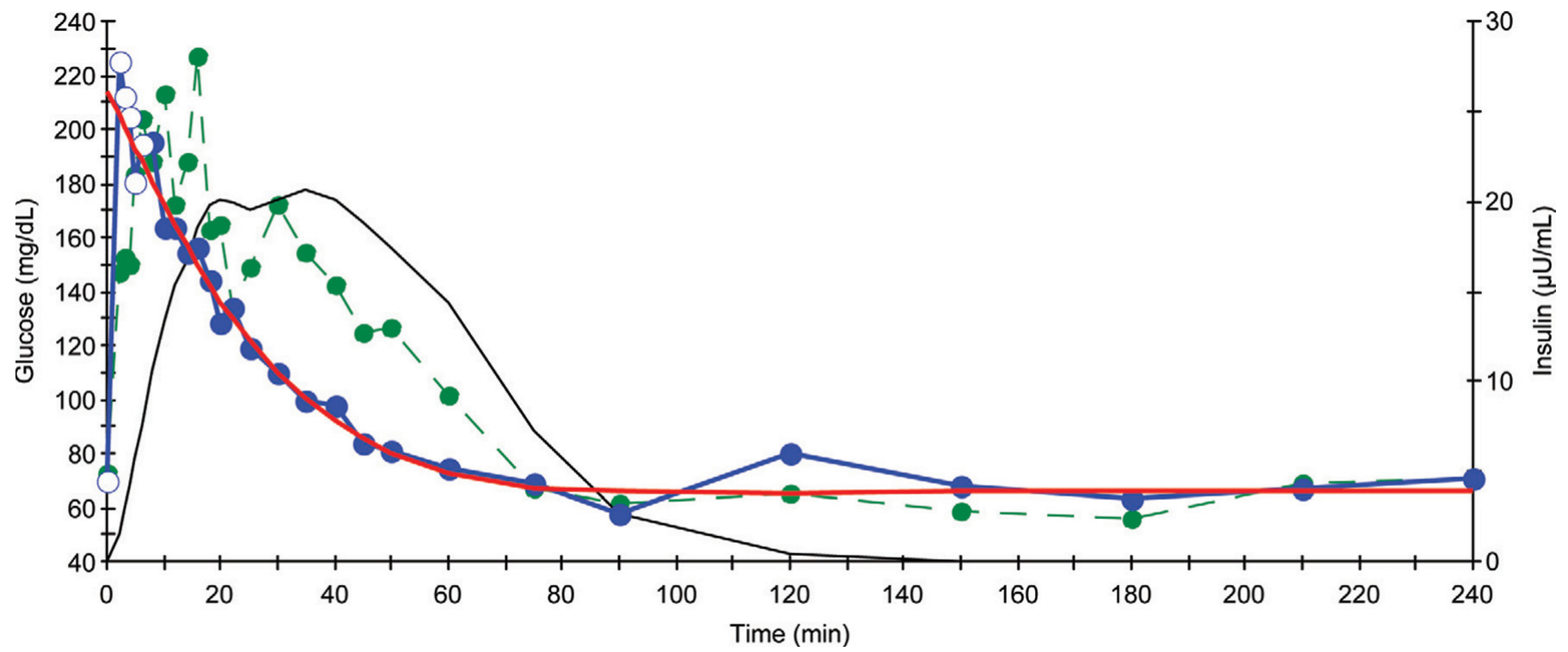

Figure 2. Example of MINMOD (MINMOD Inc., Pasadena, CA) fit in a single data set at 460 DIM describing the response of plasma glucose and insulin concentrations to a glucose infusion. Color version available online.

of glucose, NEFA, and insulin to the IVGTT indicated a change in glucose tolerance during an extended lactation. Throughout the extended lactation phase (460 and 560 DIM) cows had varied responsiveness to the IVGTT. Slower glucose CR beyond 300 DIM suggests decreased glucose tolerance and responsiveness to insulin or decreased mammary uptake of glucose due to decreased milk yield. It is difficult to reach a conclusion regarding the extent of change in sensitivity to insulin throughout the extended lactation. Thus, the initial hypothesis that insulin sensitivity would increase with increasing DIM was only partly supported by the changes in glucose metabolism.

Responses to IVGTT involve coordinated responses to insulin as well as glucose disposal that is directly related to glucose itself (Muniyappa et al., 2008). Noninsulin-mediated glucose disposal is responsible for the majority of glucose disposal in the lactating dairy cow due to glucose transport across the mammary cell membrane being typically independent of insulin (Rose et al., 1997). The initial plasma glucose response to glucose infusion $\left(\mathrm{AUC}_{0-20}\right)$ predominantly reflects this type of glucose disposal. At 560 DIM, glucose $\mathrm{AUC}_{0-20}$ was increased compared with earlier stages of the lactation, indicating that the uptake of glucose by noninsulinmediated measures was reduced and this was reflected in lower milk yield at 560 DIM.

Glucose clearance in the later stages of the IVGTT (CR 40-90) reflects mainly the indirect effects of insulin on glucose clearance although cannot be attributed to the effects of insulin alone. Glucose CR 40-90 was greatest when milk yield was high, and was not af- fected by diet, indicating that milk yield and uptake of glucose by insulin-dependent means are closely related. This could indicate either increased glucose uptake by the mammary gland or by peripheral tissues. The change in glucose CR 40-90 followed the same pattern as the peak in insulin response to glucose (Tables 2 and 3 ). The numerically lower peak in insulin observed at 250 DIM, and also AIR $_{\mathrm{g}}$ (Table 3), indicates a reduced pancreatic response to hyperglycemia. However, no difference due to stage of lactation in glucose $\mathrm{CR}$ or $\mathrm{S}_{\mathrm{I}}$ was observed (Table 3), which suggests that, although the response of insulin-sensitive tissues may have changed, whole body responsiveness to insulin was not altered. Throughout lactation, tissue sensitivity to insulin is regulated by differences in the expression of insulin receptors or glucose transporters on tissues, including the mammary gland, liver, adipose tissue, or skeletal muscle (Komatsu et al., 2005; Zhao and Keating, 2007). The use of the hyperinsulinemic-euglycemic clamp or insulin tolerance test would be valuable to establish the extent of change in tissue sensitivity to insulin during an extended lactation.

Our second hypothesis was supported, as no clear effect of diet on whole body response to the IVGTT was seen. This supports the findings of Back et al. (2007) and Chagas et al. (2003); however, an interaction between DIM and diet occurred. The glucose CR (40-90 min) was numerically lower at 100 and 250 DIM, and numerically higher at 460 and 560 DIM in the GRN treatment compared with the CON. This is consistent with the results of Chagas et al. (2009), where the fractional turnover rate of glucose was greater in cows 
fed $6 \mathrm{~kg}$ versus 0 or $3 \mathrm{~kg}$ of concentrate. The AUC for insulin for the entire challenge $(0-240 \mathrm{~min})$ were also greater in GRN compared with CON cows. Thus, glucose metabolism in GRN cows may be less responsive to insulin than CON cows throughout the lactation. These responses were unclear, and it is not possible to determine whether insulin response to an IVGTT is a function of grain feeding, greater ME intake, overall energy balance, or greater milk yield as lactation progressed.

The hypothesis that estimated whole body sensitivity to insulin would increase with increasing DIM was supported by changes in FA metabolism. The shape of the NEFA response curve to glucose infusion was markedly different at each stage of lactation. The suppression of plasma NEFA was amplified in the extended lactation phase as determined by the percentage change in NEFA concentration relative to basal (Table 2). This may be a result of increased adiposity, or an increase in insulin receptor availability as the extended lactation progressed. Patton et al. (2009) showed that the plasma NEFA response to an IVGTT in dairy cows at 32 DIM was not different to the response at 137 DIM, except that basal plasma NEFA concentration and the NEFA AUC was greater at 32 DIM. This suggests that changes in insulin responsiveness do not occur until nutrient partitioning promotes body tissue storage, rather than milk production.

No clear effect of diet on the NEFA response to the IVGTT was noted, supporting the second hypothesis. The immediate decline in plasma NEFA concentration at 100 DIM was in contrast to the initial latency period observed at subsequent stages of the lactation. It has been suggested that this latency period may be a stress response to the increased activity of research staff before a metabolic challenge (Boston et al., 2008). However, a latency period was not observed during the first sampling period of the lactation, when cows were not adapted to the experimental conditions. Recovery plasma concentrations of NEFA were consistently greater in GRN cows compared with CON cows, which may indicate an increase in lipolytic response to counter-regulatory hormones, including growth hormone, epinephrine, or cortisol (Brehm et al., 2006), involved in homeostatic regulation of FA.

The use of IVGTT during lactation is complicated due to large amounts of glucose uptake by the mammary gland in a noninsulin-dependent fashion via glucose transporters (Bell and Bauman, 1997) and rapid changes in lipid metabolism (McNamara and Hillers, 1986). Insulin sensitivity is reduced in late pregnancy (Petterson et al., 1993). The effect of pregnancy was likely to be negligible, as the cows would have been within the first trimester in the current experiment. 
However, the hormonal changes that occur during pregnancy may have affected insulin sensitivity at 560 DIM.

The shift in nutrient partitioning away from milk production and toward body tissue storage as lactation progressed (Marett et al., 2011) is associated with increased rates of lipogenesis (McNamara and Hillers, 1986). In the current experiment, cow BW increased with increasing DIM and these cows had lower plasma NEFA but greater plasma leptin concentrations (L. C. Marett, unpublished data); these data are consistent with those of Marett et al. (2011) and Delany et al. (2010). Decreased insulin sensitivity has been associated with increased body mass index in humans (Bergman et al., 1987) and with obesity in sheep (Bergman et al., 1989). It could not be determined whether insulin sensitivity or responsiveness is associated with the persistency of lactation in this experiment. However, it is possible that during the extended lactation phase, when cows have decreased milk yield but increased body fat mass, a degree of reduced glucose tolerance is maintained.

A large degree of variation in the response to the IVGTT was noted in terms of stage of lactation and dietary treatment. The current data indicate that the regulation of insulin sensitivity and responsiveness during lactation may vary between insulin-responsive tissues as a result of the mammary gland requirement of glucose for milk production. It is possible that lactation-induced insulin resistance manifests differently to obesity-induced insulin resistance, with differences in the proportion of response being related to muscle versus adipose tissue. A shift in the regulation of nutrient partitioning occurred between 100 and 250 DIM, which was more pronounced for FA metabolism. The current data suggest that variation in sensitivity and responsiveness to insulin has an important role in the regulation of nutrient partitioning during lactations up to $670 \mathrm{~d}$, but this is not easily differentiated from insulin-independent uptake of glucose by the mammary gland.

\section{CONCLUSIONS}

The current data support previous research that, after 300 DIM of an extended lactation, cows increasingly partition nutrients toward tissue gain rather than milk production. Throughout late lactation, cows exhibited reduced whole body glucose tolerance to insulin in response to an IVGTT. This did not support our original hypothesis that whole body responsiveness to insulin would increase with increasing DIM. Whole body insulin sensitivity was not affected by dietary intake at any stage of the lactation. These results indicate that the cows retained a degree of insulin resistance throughout the extended phase of the lactation to sustain milk production, in particular with regard to FA metabolism. Basal plasma glucose and insulin concentrations were consistently greater in cows fed a larger quantity of concentrate. Differences in plasma NEFA concentrations were generally reflective of milk yield, with little effect of nutrition. Understanding hormonal and metabolic regulation of insulin sensitivity with respect to milk yield and nutrient partitioning during lactation is important to developing nutritional strategies for cows managed under extended lactations.

\section{REFERENCES}

Auldist, M. J., C. Grainger, K. L. Macmillan, L. C. Marett, M. Hannah, B. J. Leury, and W. J. Wales. 2011. Feed conversion efficiency and marginal milk production responses of pasture-fed dairy cows offered supplementary grain during an extended lactation. Anim. Prod. Sci. 51:204-209.

Auldist, M. J., G. N. O'Brien, D. J. Cole, K. L. Macmillan, and C. Grainger. 2007. Effects of varying lactation length on milk production capacity of cows in pasture-based dairying systems. J. Dairy Sci. 90:3234-3241.

Back, P. J., R. Boston, C. C. Palliser, E. S. Kolver, and L. M. Chagas. 2007. Evaluation of a model that estimates insulin sensitivity in dairy cows. Proc. N.Z. Soc. Anim. Prod. 67:261-265.

Baird, D. B. 1994. The design of experiments with covariates. PhD thesis, University of Otago, Otago, New Zealand.

Bell, A. W., and D. E. Bauman. 1997. Adaptations of glucose metabolism during pregnancy and lactation. J. Mammary Gland Biol. Neoplasia 2:265-278.

Bergman, E. N., S. S. Reulein, and R. E. Corlett. 1989. Effects of obesity on insulin sensitivity and responsiveness in sheep. Am. J. Physiol. 257:E772-E781.

Bergman, R. N., Y. Ider, C. Bowden, and C. Cobelli. 1979. Quantitative estimation of insulin sensitivity. Am. J. Physiol. 236:E667E677.

Bergman, R. N., R. Prager, A. Volund, and J. M. Olefsky. 1987. Equivalence of the insulin sensitivity index in man derived by the minimal model method and the euglycemic glucose clamp. J. Clin. Invest. 79:790-800.

Borman, J. M., K. L. Macmillan, and J. Fahey. 2004. The potential for extended lactations in Victorian dairying: A review. Aust. J. Exp. Agric. 44:507-519.

Boston, R. C., J. R. Roche, G. M. Ward, and P. J. Moate. 2008. A novel model to describe non-esterified fatty acid kinetics in Holstein dairy cows. J. Dairy Res. 75:13-18.

Boston, R. C., D. Stefanovski, P. J. Moate, A. E. Sumner, R. M Watanabe, and R. N. Bergman. 2003. MINMOD Millennium: A computer program to calculate glucose effectiveness and insulin sensitivity from the frequently sampled intravenous glucose tolerance test. Diabetes Technol. Ther. 5:1003-1015.

Brehm, A., K. Thomaseth, E. Bernroider, P. Nowotny, W. Waldhausl, G. Pacini, and M. Roden. 2006. The role of endocrine counterregulation for estimating insulin sensitivity from intravenous glucose tolerance tests. J. Clin. Endocrinol. Metab. 91:2272-2278.

Busato, A., D. Faissler, U. Kupfer, and J. W. Blum. 2002. Body condition score in dairy cows; associations with metabolic and endocrine changes in healthy dairy cows. J. Vet. Med. A Physiol. Pathol. Clin. Med. 49:455-460.

Chagas, L. M., B. A. Clark, F. M. Rhodes, D. Blache, E. S. Kolver, and G. A. Verkerk. 2003. Metabolic responses to glucose challenge in New Zealand and overseas Holstein-Friesian dairy cows. Proc. N.Z. Soc. Anim. Prod. 63:31-34.

Chagas, L. M., M. C. Lucy, P. J. Back, D. Blacke, J. M. Lee, P. J. S. Gore, A. J. Sheahan, and J. R. Roche. 2009. Insulin resistance in divergent strains of Holstein-Friesian dairy cows offered fresh 
pasture and increasing amounts of concentrate in early lactation. J. Dairy Sci. 92:216-222.

Collier, R. J., J. P. McNamara, C. R. Wallace, and M. H. Dehoff. 1984. A review of endocrine regulation of metabolism during lactation. J. Anim. Sci. 59:498-510.

Cronje, P. B. 2000. Nutrient-gene interactions: Future potential applications. Pages 284-288 in Ruminant Physiology: Digestion, Metabolism, Growth and Reproduction. P. B. Cronje, ed. CAB International, New York, NY.

Debras, E., J. Grizard, E. Aina, S. Tesseraud, C. Champredon, and M. Arnal. 1989. Insulin sensitivity and responsivenessduring lactation and dry period in goats. Am. J. Physiol. 256:E295-E302.

Delany, K. K., K. L. Macmillan, C. Grainger, P. C. Thomson, D. Blache, K. R. Nicholas, and M. J. Auldist. 2010. Blood plasma concentrations of metabolic hormones and glucose during extended lactation in grazing cows or cows fed a total mixed ration. J. Dairy Sci. 93:5913-5920.

Denbow, C. J., K. S. Perera, F. C. Gwazdauskas, R. M. Akers, R. E. Pearson, and M. L. McGilliard. 1986. Effect of season and stage of lactation on plasma insulin and glucose following glucose injection in Holstein cattle. J. Dairy Sci. 69:211-216.

Evans, E., J. G. Buchanan-Smith, G. K. MacLeod, and J. B. Stone. 1975. Glucose metabolism in cows fed low- and high-roughage diets. J. Dairy Sci. 58:672-677.

Grainger, C., M. J. Auldist, G. O'Brien, K. L. Macmillan, and C. Culley. 2009. Effect of type of diet and energy intake on milk production of Holstein-Friesian cows with extended lactations. J. Dairy Sci. 92:1479-1492.

Holtenius, K., S. Agenas, C. Delavaud, and Y. Chilliard. 2003. Effects of feeding intensity during the dry period 2. Metabolic and hormonal responses. J. Dairy Sci. 86:883-891.

Jenny, B. F., and C. E. Polan. 1975. Postprandial blood glucose and insulin in cows fed high grain. J. Dairy Sci. 58:512-514.

Johnson, M. M., and J. P. Peters. 1993. Technical note: An improved method to quantify nonesterified fatty acids in bovine plasma. J. Anim. Sci. 71:753-756.

Kay, J. K., C. V. C. Phyn, J. F. Roche, and E. S. Kolver. 2009. Extending lactation in pasture-based dairy cows II: Effect of genetic strain and diet on plasma hormone and metabolite concentrations. J. Dairy Sci. 92:3704-3713.

Kolver, E. S., J. R. Roche, C. R. Burke, J. K. Kay, and P. W. Aspin. 2007. Extending lactation in pasture-based dairy cows: I. Genotype and diet effect on milk production. J. Dairy Sci. 90:5518-5530.

Komatsu, T., F. Itoh, S. Kushibiki, and K. Hodate. 2005. Changes in gene expression of glucose transporters in lactating and nonlactating cows. J. Anim. Sci. 83:557-564.

Marett, L. C., M. J. Auldist, C. Grainger, W. J. Wales, D. Blache, K. L. Macmillan, and B. J. Leury. 2011. Temporal changes in plasma concentrations of hormones and metabolites in pasture-fed dairy cows during extended lactation. J. Dairy Sci. 94:5017-5026.

McClary, D. G., J. L. Sartin, R. J. Kemppainen, and J. C. Williams. 1988. Insulin and growth hormone responses to glucose infusion in mature and first-lactation dairy cows. Am. J. Vet. Res. 49:17021704 .

McNamara, J. P., and J. K. Hillers. 1986. Adaptations in lipid metabolism of bovine adipose tissue in lactogenesis and lactation. J. Lipid Res. 27:150-157.

Muniyappa, R., S. Lee, H. Chen, and M. J. Quon. 2008. Current approaches for assessing insulin sensitivity and resistance in vivo: advantages, limitations, and appropriate usage. Am. J. Physiol. Endocrinol. Metab. 294:E15-E26.
Patton, J., J. J. Murphy, F. P. O'Mara, and S. T. Butler. 2009. Responses of North American and New Zealand strains of HolsteinFriesian dairy cattle to homeostatic challenges during early and mid-lactation. Animal 3:251-260.

Petterson, J. A., F. R. Dunshea, A. Ehrhardt, and A. W. Bell. 1993. Pregnancy and undernutrition alter glucose metabolic responses to insulin in sheep. J. Nutr. 123:1286-1295.

Pires, J. A. A., A. H. Souza, and R. R. Grummer. 2007. Induction of hyperlipidemia by intravenous infusion of tallow emulsion causes insulin resistance in Holstein cows. J. Dairy Sci. 90:2735-2744.

Prior, R. L., and R. K. Christenson. 1978. Insulin and glucose effects on glucose metabolism in pregnant and nonpregnant ewes. J. Anim. Sci. 46:201-210.

Reist, M., D. Erdin, D. von Euw, K. Tscheumperlin, H. Leuenberger, Y. Chilliard, H. M. Hammon, C. Morel, C. Philipona, Y. Zbinden, N. Keunzi, and J. W. Blum. 2002. Estimation of energy balance at the individual and herd level using blood and milk traits in highyielding dairy cows. J. Dairy Sci. 85:3314-3327.

Ronge, H., J. W. Blum, C. Clement, F. Jans, H. Leuenberger, and H. Binder. 1988. Somatomedin C in dairy cows related to energy balance and protein supply and to milk production. Anim. Prod. 47:165-183.

Rose, M. T., Y. Obara, F. Itoh, H. Hashimoto, and Y. Takahashi. 1997. Non-insulin and insulin-mediated glucose uptake in dairy cows. J. Dairy Res. 64:341-353.

Sano, H., S. Narahara, T. Kondo, A. Takahashi, and Y. Terashima. 1993. Insulin responsiveness to glucose and tissue responsiveness to insulin during lactation in dairy cows. Domest. Anim. Endocrinol. 10:191-197.

Sartin, J. L., K. A. Cummins, R. J. Kemppainen, D. N. Marple, C. H. Rahe, and J. C. Williams. 1985. Glucagon, insulin, and growth hormone responses to glucose infusion in lactating dairy cows. Am. J. Physiol. 248:E108-E114.

Schoenberg, K. M., R. M. Erhardt, and T. R. Overton. 2012. Effects of plane of nutrition and feed deprivation on insulin responses in dairy cattle during late gestation. J. Dairy Sci. 95:670-682.

Sorensen, A., and C. H. Knight. 2002. Endocrine profiles of cows undergoing extended lactation in relation to the control of lactation persistency. Domest. Anim. Endocrinol. 23:111-123.

Sorensen, A., D. D. Muir, and C. H. Knight. 2008. Extended lactation in dairy cows: effects of milking frequency, calving season and nutrition on lactation persistency and milk quality. J. Dairy Res. 75:90-97.

Tindal, J. S., G. S. Knaggs, I. C. Hart, and L. A. Blake. 1978. Release of growth hormone in lactating and non-lactating goats in relation to behaviour, stages of sleep, electroencephalograms, environmental stimuli and levels of prolactin, insulin, glucose and free fatty acids in the circulation. J. Endocrinol. 76:333-346.

Vernon, R. G., and C. M. Pond. 1997. Adaptations of maternal adipose tissue to lactation. J. Mammary Gland Biol. Neoplasia $2: 231-241$.

Williams, S. R. O., T. Clarke, M. Hannah, L. C. Marett, P. J. Moate, M. J. Auldist, and W. J. Wales. 2013. Energy partitioning in herbage-fed dairy cows offered supplementary grain during an extended lactation. J. Dairy Sci. 96:484-494.

Zhao, F. Q., and A. F. Keating. 2007. Expression and regulation of glucose transporters in the bovine mammary gland. J. Dairy Sci. 90(E. Suppl 1):E76-E86. 